Marko Neumann*

\title{
Punctuation and text segmentation in 15th-century pamphlets
}

https://doi.org/10.1515/zfs-2021-2035

Published online November 17, 2021

\begin{abstract}
The use of punctuation in German incunabula is often described as arbitrary, irregular, and unsystematic (cf. Masalon 2014: 54-56). This concerns the inventory, frequency, and function of punctuation marks as well as pragmatic aspects such as how typesetters treated punctuation in their respective target texts. In this paper, punctuation is not seen as an independent linguistic subsystem, but as a means of text segmentation that - along with other measures (e. g. capital letters, pilcrows, and white space) - was used to structure a text with respect to its formal appearance, helping the reader to decode information. This case study is based on a corpus of German pamphlets written by the Bohemian astrologer Wenzel Faber and printed annually beginning in 1481 at various print shops, principally in Leipzig and Nuremberg. The analysis finds significant changes in the editions before and after 1490 . These changes include an increasing consistency in the intensity of text segmentation, and a use of capital letters and punctuation marks developed from a polyfunctional to a monofunctional approach. Finally, different types of text segmentation are proposed, each characterized by a specific relationship between its frequency and its function. Despite this overall tendency, one must still take into account that typesetters followed individual punctuation practices in their search for suitable forms of text segmentation.
\end{abstract}

Keywords: punctuation, capitalization, incunabula, 'Practica Deutsch'

\section{Introduction}

The last quarter of the 15th century is an important phase in the history of German punctuation, as basic features of our modern punctuation system were explored and consolidated in printers' search for suitable forms of text segmentation. While early years of letterpress printing were characterized by technological advances, after initially adopting the layout traditions of handwritten manuscripts, printers gradually began to rethink layout strategies from a strictly typographical point of

\footnotetext{
*Corresponding author: Marko Neumann, Institut für Gemanistik, Justus-Liebig-Universität Gießen, Otto-Behaghel-Str. 10 B, 35394 Gießen, Germany, e-mail:

Marko.Neumann@germanistik.uni-giessen.de
} 
view and started to produce large quantities of uniform texts with more readerfriendly appearances in order to attract additional groups of buyers and readers. ${ }^{1}$ The craftsmen involved (e. g. typesetters, correctors, rubricators, illuminators) still drew on structural aids from medieval manuscripts, such as pilcrow signs, illuminated initials, and underlining in red ink. At the same time, they applied new methods, such as different type sizes and indented paragraphs in conjunction with a freer handling of white space, to edit texts in a way that increased comprehensibility. ${ }^{2}$ It seems reasonable to evaluate punctuation and capitalization in line with these developments, as the insertion of punctuation marks and the use of capital letters provided additional semantic, syntactic and/or prosodic information that also helped the reader to facilitate and accelerate the reading process (cf. Lennard 1995). Both features are considered as means of text segmentation - text segmentation being the process of structuring a given text with regard to its formal appearance. Its main purpose is to support the reader in decoding information. ${ }^{3}$

Several studies on historical punctuation (e.g. Simmler 2003: 2479-2481, Kirchhoff 2017: 169-171) have demonstrated that uses of punctuation marks and capital letters can be interpreted syntactically as early as the 15 th century. ${ }^{4}$ However, the assumption of a "syntactic principle" of punctuation does not explain why typesetters in print shops pursued individual punctuation practices, deviated considerably from handwritten templates, and inserted punctuation marks in a division of labor e. g. with rubricators (cf. Voeste 2018; Neumann and Voeste 2022). ${ }^{5}$ To some extent, the syntactic perspective obscures the practical problem of printers' attempts to find purposeful strategies of text segmentation. Before capitalization and punctuation were linguistically differentiated, the structuring of a text had to be consolidated at least in its basic features.

1 For a current state of research on the emergence of the "modern" book, see Rautenberg (2018: 307-318) and Schmitz (2018: 129-144).

2 For a systematic overview of graphical means for reader guidance, see Rautenberg (2018: 298-300). Griese (2017) emphasizes the continuation of layout traditions from the manuscript era in 15th-century printing. For a typology of paragraph forms, see Janssen (2005: 13-14).

3 In this sense, text segmentation is closely related to the French concept of mise-en-page and mise-en-text (cf. Laufer 1983). On text segmentation in the field of text linguistics, see Stein (2003: 16-19).

4 In these studies, the aspect of text segmentation plays a minor role (cf. only Lemke 2020: 90-94). Simmler (2003: 2473) assumes bundles of features ('Repräsentationstypen') comprising means of punctuation, orthography and text segmentation.

5 In a way, printers and editors can therefore be described as "interpreters" and "textual critics" of the texts they presented (cf. Smith 2019: 149-150). 
The aim of this paper is to identify the main types of text segmentation on an empirical basis. The case study begins with an introduction of the historical data employed, i. e. pamphlets with astrological prognostications written by Wenzel Faber in the 1480s and 1490s. This includes an analysis of paratextual devices, content structure, and syntactic patterns, as the importance of text segmentation for readers' reception becomes obvious in the context of these textual characteristics. In the main part of this paper, the investigation of text segmentation practices concentrates on two central aspects. First, the intensity of segmentation will be evaluated, considering all methods actually employed in the corpus. Second, the paragraph-internal relationship between capitalization and punctuation will be examined with respect to their frequency and function. This will lead to a classification of different approaches to the treatment of punctuation marks and capital letters in the process of text segmentation.

\section{Wenzel Faber and his 'Practica Deutsch'}

Despite being one of the most frequently printed authors of his time, Wenzel Faber (c. 1455-1518) belongs to the forgotten figures from the early period of letterpress printing (cf. Milway 2000: 142). Even incunable studies and other historical sciences have taken little interest in him or his work. ${ }^{6}$ Born in Budweis (České Budějovice) into rather modest circumstances, Faber pursued an academic career in Leipzig, and found success as a highly respected astronomer and physician in the German-speaking territories. The Gesamtkatalog der Wiegendrucke (GW) lists more than 100 incunable editions with Faber as the author, printed mainly in Leipzig as well as in Ingolstadt, Nuremberg, Augsburg, Mainz, Passau, Magdeburg, and Erfurt. ${ }^{7}$

In the 1480s and 1490s, Faber was the leading author of astronomicalastrological prognostications ${ }^{8}$ containing forecasts of natural phenomena for one year. These pamphlets of eight to twelve leaves were published annually in German and Latin, supposedly intended as Christmas gifts or New Year's greetings (cf. Green 2012: 8). Depending on whether they were printed in the previous or current year of the forecast, the predictions started either in January (Jenner) or

6 Cf. only Green (2011: 117-199, 2012: 9-10) and Voeste (2020).

7 See https://www.gesamtkatalogderwiegendrucke.de/ (October 2020).

8 Faber's influence is well documented in a public feud with Paul Eck over who would reign supreme as author of practicas in Leipzig, at the end of which Eck stopped publishing his texts (cf. Haebler 1914). 


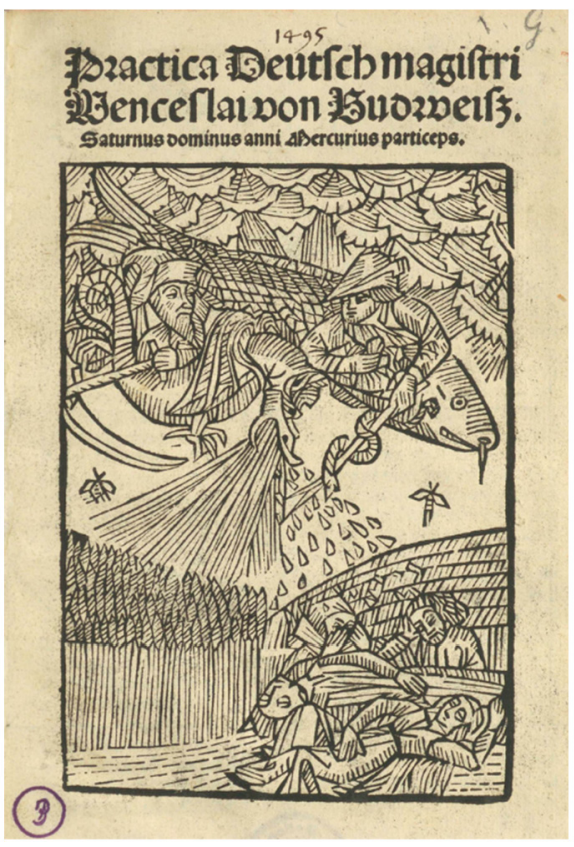

Figure 1: Title page of Faber’s 'Practica Deutsch' (Nuremberg: Koberger, 1494/95) ${ }^{9}$.

February (Hornung). As most pamphlets do not provide any printing information, they are usually cited with both possible years of publication. The oldest available edition is dated to $1482 / 83$, the latest one to $1506 / 07$. When printers began to use title pages, Faber's prognostications were often designated as 'Practica Deutsch' and 'Iudicium lipsense', respectively (cf. Figure 1). While, at the time, practica referred to texts of many scientific areas, including law, medicine, and music, it became a proper generic term for prognostications during the first half of the 16th century (cf. Kremer 2017). By contributing to the emergence of characteristic features, Faber influenced the genre decisively.

There are several reasons Faber's practicas are a valuable source for the investigation of segmentation practices. First and foremost, the vast number of copies that have survived until today allow us to examine the practices of various print shops over a period of approximately twenty years. Hence, it can be clarified, for example, to what extent the editions produced by Faber's preferred printers

9 Österreichische Nationalbibliothek, Ink 1.G.64 (GW 9612). 
in Leipzig differ from reprints in other places. Given their ephemeral nature, ${ }^{10}$ the practicas were most likely produced at low cost, with printers not deploying their most qualified typesetters. Thus Faber's practicas reveal the usual, expedient practices in 15th-century print shops, and not the more elaborated ones. From a reader's perspective, practicas were meant more for cursory than for intensive study (cf. Green 2012: 7-8). Text segmentation therefore played an essential role for orientation within the text, especially since practicas were also meant to appeal to inexperienced readers. ${ }^{11}$ While many early printers adhered to the layout of medieval manuscripts, an adaptation of manuscript practices can be precluded for Faber's practicas: with astrological practicas evolving in the mid-1470s all across Europe, their origin and appearance was strongly linked to letterpress printing. $^{12}$

When compiling the corpus for this study, the aim was to include all 32 German editions listed in the Gesamtkatalog der Wiegendrucke. ${ }^{13}$ For a number of reasons, only 25 editions could be procured, along with one additional edition owned by the University of Warsaw Library (cf. the table of corpus texts in the reference section). Of these 26 editions in total, all printed in quarto, 13 copies are fragments of a few leaves, which reflects the condition of many early practicas today. ${ }^{14}$ Most editions were printed either in Leipzig or in Nuremberg (10 editions each), but there is also one edition each from Passau, Augsburg, Mainz, Lübeck, Magdeburg, and Erfurt. Besides Martin Landsberg, who was among the most productive and influential printers of his time, ${ }^{15}$ Faber's first printers in Leipzig included Martin Brandis and Gregor Boettiger, and perhaps even the famous and success-

10 Since practicas became obsolete after one year, they were not infrequently reused in bookbinding. Some editions (e. g. GW 9587) have only survived as fragmentary maculature preserved in the binding of another work.

11 On aids for orientation in Early New High German herbal books, cf. Habermann (2001: 132-167).

12 Apart from Wenzel Faber, German pioneer authors include Johann von Glogau, Martin Polich, and Johannes Virdung. The golden age of practicas was in the later 16th century with 30 or more different authors active at one time (cf. Green 2012: 8-15).

13 GW 9587 and GW 958710 N are most likely fragments of the same edition. GW 9586 was published in 1489/90 (not in 1485/86), as a comparison with the respective editions proves. There are no further editions listed in the Incunabula Short Title Catalogue (ISTC; October 2020).

14 On challenges for researchers in determining the authorship, printing house and publication date of early German fragmentary practicas, see Green and Duntze (2013).

15 On Landsberg's life and work, see Franck (1883). According to Geldner (1968: 245) and Reske (2015: 557), Landsberg probably printed under the alias of Capotius in the mid-1480s. Thus GW $959310 \mathrm{~N}$ would be assigned to him. 
ful printer, publisher, and bookseller Konrad Kachelofen. ${ }^{16}$ Among the reprinters, we find both highly productive, financially prosperous, and distinguished printers (e. g. Anton Koberger and Friedrich Creussner) and printers of whom very little is known (e.g. Moritz Brandis, and Heidericus and Marx Ayrer). ${ }^{17}$ The enormous number of printers who published Faber's practicas indicates a high demand for prognostications during the incunable era and the great popularity of the genre.

\section{Paratexts, content structure, and syntactic units}

Paratexts are elements of a book that accompany or frame the main text; examples included title pages, indexes, page headers, marginalia, catchwords and illustrations. Their basic function is to help the reader access the book, or as Genette (1997: 1-2) puts it: "More than a boundary or a sealed border, the paratext is, rather, a threshold, [...] a 'vestibule' that offers the world at large the possibility of either stepping inside or turning back.” It is generally agreed that while paratexts were not "invented" in letterpress printing, their stabilization, differentiation, and dispersion were greatly enhanced by the new technologies. ${ }^{18}$ Faber's practicas, nevertheless, show hardly any paratextual devices. Apart from title pages in later editions (typically with a woodcut in central position) ${ }^{19}$ and sporadic indication of section and page, ${ }^{20}$ the practicas only consist of main text and chapter headings. The sparse paratextual equipment made it more difficult for readers to approach and decode the content of the pamphlet. Accessibility and reader orientation thus had to be achieved mainly by means of text segmentation.

While paratexts were usually created by employees in the print shops, ${ }^{21}$ the content structure and linguistic form of the practicas were certainly predetermined by Faber's manuscripts. ${ }^{22}$ This becomes evident in the fact that - as re-

16 Cf. the Gesamtkatalog der Wiegendrucke. Considering that in his feud with Paul Eck (cf. fn. 8), Faber publicly accused Kachelofen of unfair competition (Haebler 1914: 201), it seems rather questionable that GW 962510 was printed in Kachelofen's print shop.

17 On the role and status of the mentioned printers, see Geldner (1968) and Reske (2015).

18 Cf. Habermann (2001: 77-79) and von Ammon and Vögel (2008).

19 GW 9601 (without woodcut), GW 9602, GW 9608, GW 9609, GW 9611, GW 9612, GW 9617, GW 9619, GW 9620, GW 9622, GW 9623, GW 9624.

20 GW 9606, GW 9608, GW 9612, GW 9619, GW 9620, GW 9622, GW 9623, GW 962510.

21 On the correctors' tasks in early printing, see Grafton (2011: 10-32).

22 As far as I know, no handwritten manuscripts have been preserved. It is difficult to say whether printers outside Leipzig used the author's manuscript as a template or a copy of the first printed 
gards structure and language - no substantial changes can be detected between editions printed by different printers in the same year. However, when looking chronologically at all the editions in the corpus, one can see that the content structure of the practicas changed over time (cf. Figure 2). In the first analyzed edition (Leipzig: Brandis, 1481/82), the content is divided into a preface and seventeen chapters or so-called "words" (Worte). The "words" are presented in a linear or successive order (type I) starting off with a discussion about the scale of astronomic predictions and the ruling planets for the next year, then moving on to predictions about the weather, finances, and health as regards the four qualities (hot, cold, wet, dry), the four seasons (spring, summer, fall, winter), the moon phases (new moon and full moon of January, February, March etc.), the three religions (Judaism, Christianity, Paganism), agriculture (fruits, animals, fish), pestilence and other illnesses, war and peace as well as sending messages. Faber then continues with predictions for the highest estate (the pope, cardinals, kings, princes), people of various lands, kingdoms and cities (e. g. Meissen, Bohemia, Hungary; Leipzig, Prague, Nuremberg) and certain representatives of urban society (e.g. students and learned people, virgins and women, merchants and clerics). The practica ends with a "word" on ores and metals (e. g. gold, silver, lead) and predictions for the common people.

In the three subsequent editions (type II), the linear order was altered by an implementation of hierarchical elements constituting three chapters, each of which comprise a certain number of "words". There are no new topics, and the length of the "words" equals that found in type I. But the order of appearance was modified, with e. g. the four seasons and the moon phases being treated more prominently in chapter two. By 1487, another structure was found and kept until the last edition investigated (type III). ${ }^{23}$ Here, the preface is followed by two sections. The first section is based on fifteen chapters, mostly containing predictions for specific groups of people, which were previously combined in the "words" on the highest estate and urban society. The second section consists of three chapters with forecasts for the seasons, months, and days of the year, forming a wellbalanced counterpart to the first section.

Green (2012: 9-10) evaluates the first two types of content structure as "an exercise in chaos", and he considers the changes made during the 1480s as "radical". Therefore, it will be interesting to see whether these changes are congruent

edition. Given its brief utility value, it is quite unlikely, however, that multiple handwritten manuscripts existed.

23 Only one edition (Lübeck: Ghotan, 1491/92) shows an entirely different structure, which was probably due to the transfer from High German to Low German. 


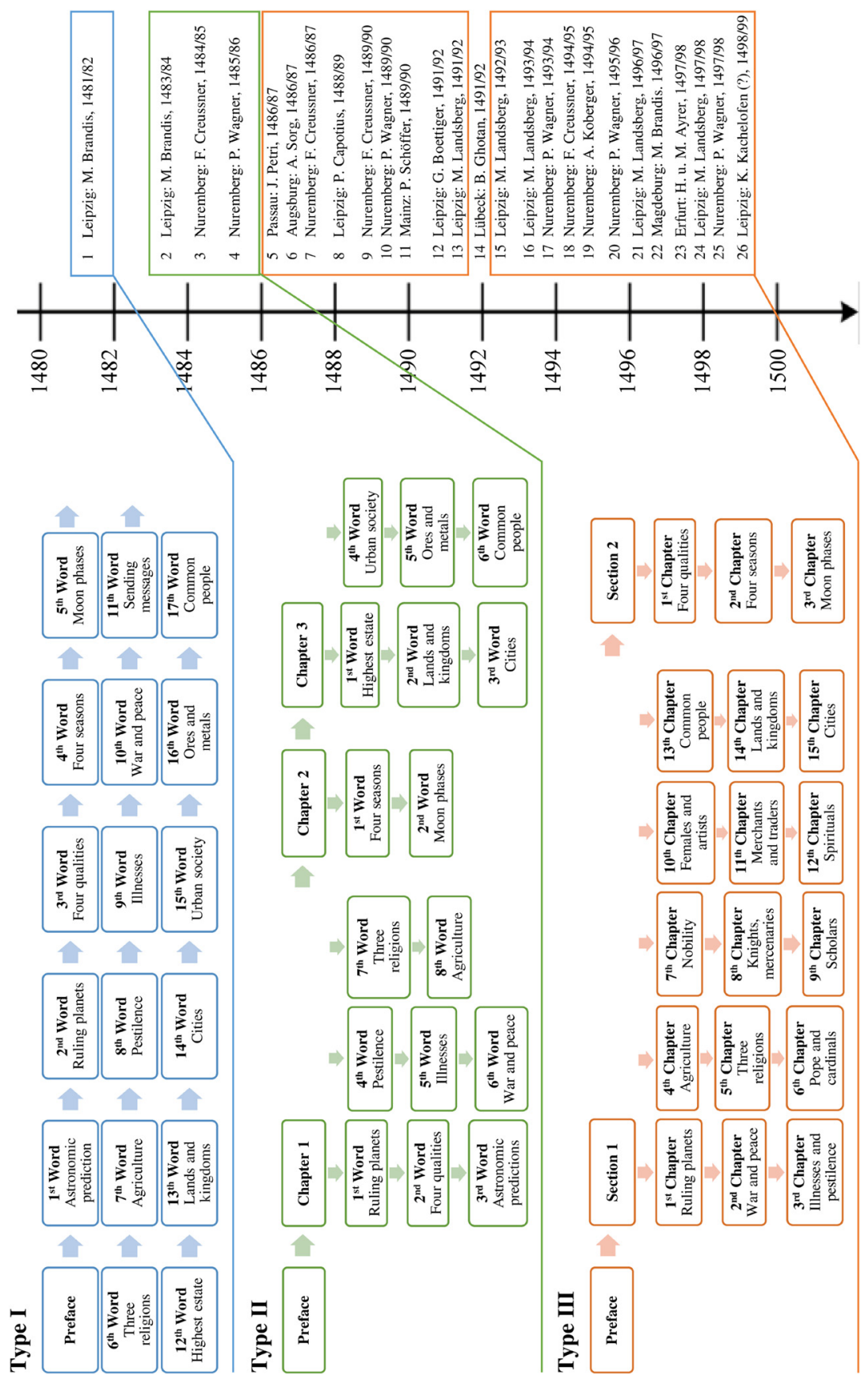

Figure 2: Changes in content structure. 
with developments in text segmentation. Apart from alterations in the order of the chapters, most content features, however, were kept surprisingly stable. The range of topics, the internal structure of the chapters and also their length were fixed right from the beginning. This is especially true of the chapter on the moon phases. Even though this chapter initially appeared closer to the front and later in the back, its internal structure is characterized by high uniformity. Each month is divided into new moon, full moon, and the days of syzygy, creating a clear and reliable structure. Since this section is the most extensive one, taking up almost half of the whole text, it is especially suitable for further analysis.

A high level of consistency also applies to the syntax of this chapter. At all chronological stages, a recurrence of formulation patterns can be detected, as illustrated for the days of July (Heumond) in (1), (2) and (3). ${ }^{24}$

(1) Am tag petri feuchtikeit mit winde in vil enden uff den mor Bei vnfzer frauwen tag trub wulkē mit Jtarckem winde kelten nach der bequemikeit $d^{s} z c e i t$ / in vil enden mit regen (Leipzig: Brandis, 1481/82)

'On the day of peter humidity with wind in many points on the sea On mary’s day gloomy clouds with strong wind coldness after the manner of time / in many points with rain'

(2) Mōtag vor viti auff die nacht wīdig. Donnerftag nach viti an vil endè milte regē. Mitwoch vor iohānis baptifte feuchtikeit. vnd an etlichē endē wirt es vor kūmen. (Nuremberg: Creussner, 1484/85)

'Monday before vitus at night windy. Thursday after vitus at many points mild rain. Wednesday before john baptist humidity. and at many points it will happen.'

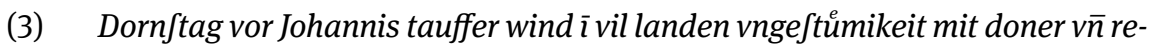
gen · in ettlichen landen wirt es vorkūmen · Frë̈tag vor johannis auff die nacht wandlung Am abent iohannis tauffer die nacht wind mit doner · (Augsburg: Sorg, 1486/87)

'Thursday before John baptist wind in many lands storm with thunder and rain · in many lands it will happen · Friday before john at night change In the evening john baptist the night wind with thunder .'

The examples above show a distinct arrangement: first, a certain day of the liturgical year is mentioned, followed by a description of the expected weather situation. After a few predictions, an established wording occurs, assuring that the predic-

24 The English translations follow the original texts closely. The uses of capital letters and punctuation marks are retained. 
tions will prove to be true in many places in the country. This specific composition is reflected in a fragmented syntax lacking in verbs. While the nominal nature of these constructions ensures information density, it poses a potential barrier in the decoding process for the reader, increasing the demand for the text segmentation to provide insight.

In conclusion, content and language of the practicas are very consistent. All texts deal with the same topics, have a largely stable chapter-internal structure, and show stereotypical expression patterns. From this, one can assume that printers (directly or indirectly) reproduced Faber's templates in a quite accurate manner. With regard to text segmentation, however, there was no joint practice common among the printers, as will be discussed in the following section.

\section{Practices of text segmentation}

The following analysis focuses on the chapter about moon phases. Since this chapter is characterized by homogeneous structure and language, a comparison between the different editions is particularly viable. Also, the chapter is the most extensive one, ensuring that even most (though not all) of the fragmentary editions can be included in the analysis. Overall, the analysis is based on 20 of the 26 editions from the corpus. ${ }^{25}$ Depending on which excerpts have survived in the copies, the number of words examined is between c. 400 and 3.100 words (36.000 words in total). The analysis begins with an introduction of each method of text segmentation. Then the intensity of heading and paragraph-external segmentation will be measured and compared. Finally, the ratio between paragraphinternal capitalization and punctuation will be examined in order to determine the main types of text segmentation.

\subsection{Means of text segmentation}

Text segmentation involves various macro- and microtypographic elements. ${ }^{26}$ In Faber's practicas, the arrangement of white space, the choice of type size, and

25 In the following fragmental editions, no excerpts from the moon phase chapter can be found: no. 5 (GW 9591), no. 8 (GW 959310N), no. 9 (GW 9596), no. 18 (GW 9611), no. 23 (GW 9622), and no. 26 (GW 962510). The editions' numbers, here and in Figures 6 to 8, refer to the table of corpus texts in the reference section.

26 On characteristics of micro- and macrotypography, see Spitzmüller (2013: 12-13). 


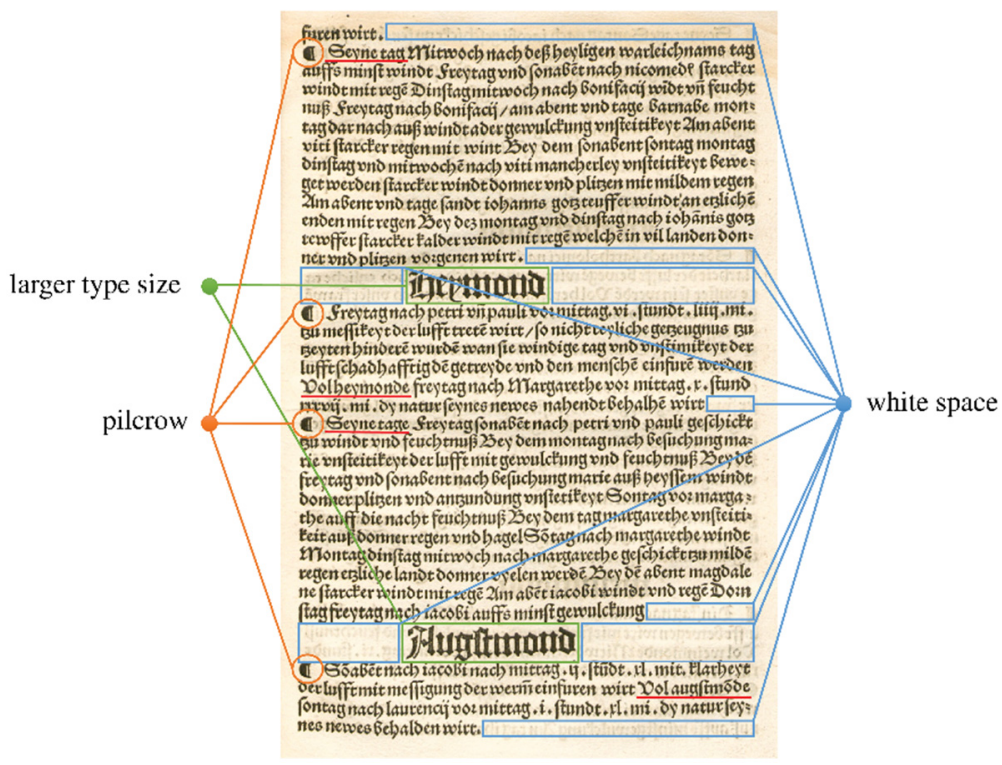

Figure 3: Means of text segmentation (Leipzig: Landsberg, 1496/97) ${ }^{27}$.

the use of pilcrow signs ${ }^{28}$ are very prominent features. ${ }^{29}$ By applying these methods, the text was divided into headings and text blocks ${ }^{30}$ (cf. Figure 3). Conversely, however, not all headings were typographically highlighted: the subheadings Volheymonde and Vol augftmōde (underlined in red) appear together with the preceding and following paragraph in one text block, seemingly without any typographical effort. ${ }^{31}$ Despite the initial pilcrow signs, Seyne tag/Seyne tage are not instantly recognizable as headings either.

Capital letters and punctuation marks were also used in the process of text segmentation, both for headings and for paragraph-internal structuring. Typeset-

27 Bayerische Staatsbibliothek, 4 Inc.s.a. 408 f (GW 9619, fol. Biiir ${ }^{\mathrm{r}}$.

28 The pilcrow (or paragraph sign) appears regularly only from 1491/92 onwards.

29 None of the copies examined were edited with red ink.

30 Text block here refers to units of text typographically arranged in a rectangular shape. Paragraphs are content units of text seperated from other content units. According to Janssen (2005) paragraphs and text blocks did not necessarily coincide in the 15th century.

31 In Figure 3, the subheadings coincide with the beginning or end of a line. While line breaks per se must be taken into account as a tool for text segmentation (cf. Neumann and Voeste 2022), the combination in this case seems to be unintentional. The copy contains many examples with the respective subheadings positioned in the middle of a line. 


\section{aterty}

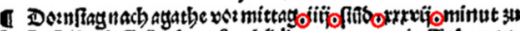

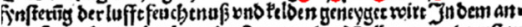

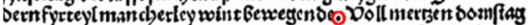

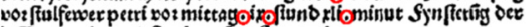
luffemit wint end feucletnu jetmfuren reirto

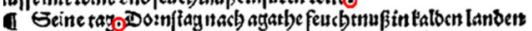

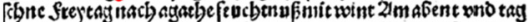

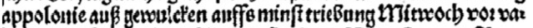

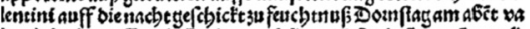

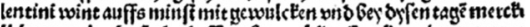

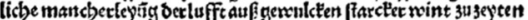

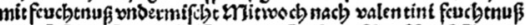

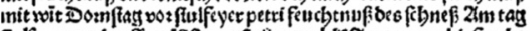

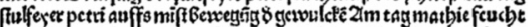

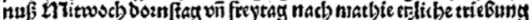

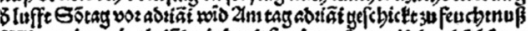

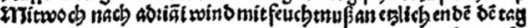
Sartach merto

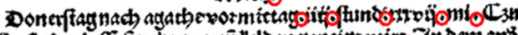

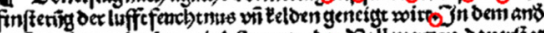

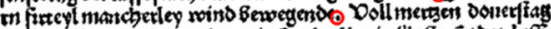

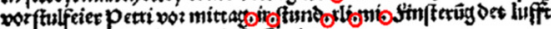
mit wotio vnd feuchtrus eintivin woirto

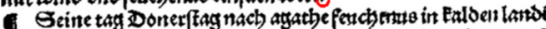

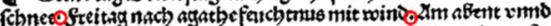

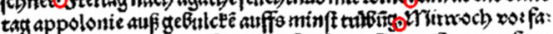

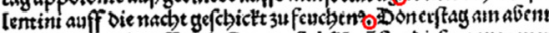
valentini wind auffis minft mute gefulcte vinbey diefen tagen mit

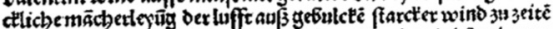

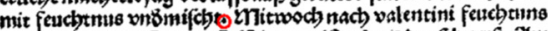

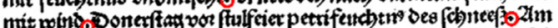

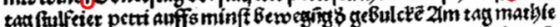

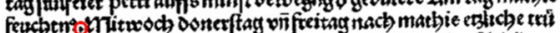

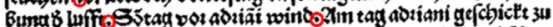

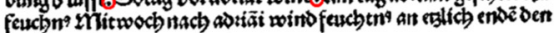
my oarnach to

Figure 4: Divergent uses of punctuation marks (left: Leipzig: Landsberg, 1493/94; right: Nuremberg: Wagner, 1493/94).

ters opted for the point (or punctus) as their preferred punctuation mark; within paragraphs, they used the virgule (or virgula suspensive) at times. ${ }^{32}$ Strikingly, the frequency in which punctuation marks and capital letters were employed varies greatly from edition to edition. Figure 4 contrasts the weather predictions for March 1494 in the editions from Leipzig and Nuremberg. The text is almost identical, as are the words marked with capital letters. Yet, the use of punctuation marks (in red) differs significantly (10 : 25). While Martin Landsberg hardly ever used punctuation marks for paragraph-internal segmentation, Peter Wagner regularly employed them in combination with capital letters.

With capital letters matters are quite similar. When comparing the Landsberg edition with an edition printed ten years earlier by Martin Brandis (cf. Figure 5), we can observe a different handling of capitalization. Brandis used capital letters (in blue) not only at the beginning of a new semantic-syntactic unit (e.g. Am Sonabende, Am mantage), but also for the days of saints (e.g. Mathie, Adriani, Greorij). In Landsberg's edition, all saints' names were printed with lowercase letters (in yellow; e. g. agathe, appolonie, valentini).

It becomes clear that punctuation and capitalization were the central techniques of paragraph-internal segmentation. With respect to their frequency and functional range, printers adopted different approaches. Systematic differences are reflected in the intensity of segmentation.

32 The same is true for late medieval medical recipe books (cf. Almeida 2001: 229). I follow the terminology proposed by Parkes (1992: 306-307). 


\section{Smeres}

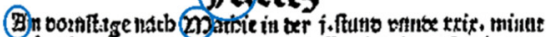
me mituge. 3 tu watholuinge oer luffe mic wint aus mittcrua

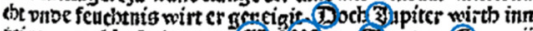
netigenit cakklarbeit. (2)

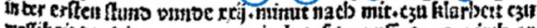
mefikeit of bites vind çu wintb aus om ufrgange wirtb er geneigetb.

\section{S) ine tage}

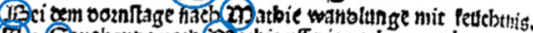
(3) (S) mabenoe nicb) (2) atbic uff oic nacht wanolunge uff

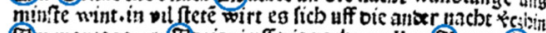

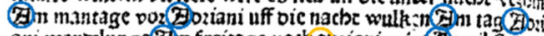

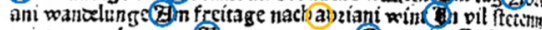
wirt cg roz kommen(2) mantage voz (G) zegozy uff oic nacht Wuiken.in vil encen wirt es vor kómen żm Gonabeno nabb

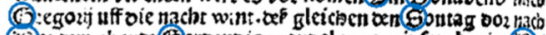

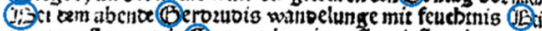
din oo:nltage nach (B) erosuois wint, uff s minfte mit regchn.

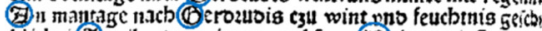

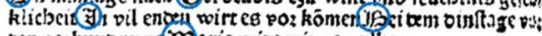
or vozkunounge(2n)arie wint mit gewulken.

\section{(Atets}

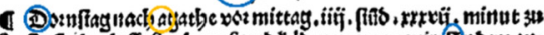

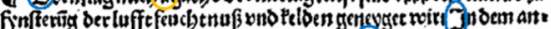

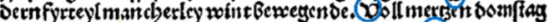
vor ftulfewer pitri voz mittag. ix. fiuno xli. minut S S nffering oec luftemit witne xno fencl) thuf etenfuren reirt.

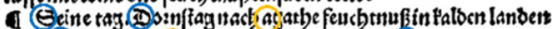

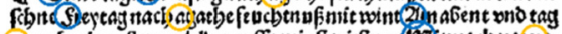

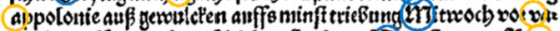

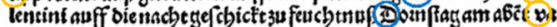
lentini wint auffo min fi mit gewoulcten bn b bey by fen tagē merch liche mancherleyigg ocrlasf auf $\$$ gemulcten ftarcter wint 3 useyten

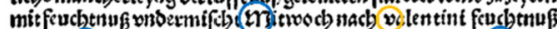

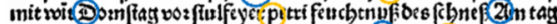

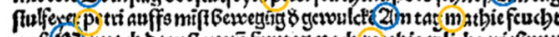

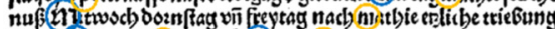

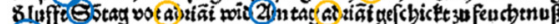

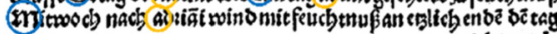
( Sarnacb

Figure 5: Divergent uses of capital letters (left: Leipzig: Brandis, 1483/84; right: Leipzig: Landsberg, 1493/94).

\subsection{Intensity of segmentation}

The intensity of segmentation describes how strong a text is segmented, i. e. how many means of segmentation are applied. To measure this, it is important to look at headings and paragraphs individually. Figures 4 and 5 illustrate different ways in which headings and paragraphs were segmented; the analysis is presented in Tables 1 and 2 ( $\checkmark$ stands for "existing”, $\boldsymbol{x}$ for "not existing”). It is important to notice that different segmentation methods not only apply to the three types of headings within one edition (1. new moon, 2. full moon, 3. days of syzygy), but also when comparing the three editions with each other: in all three editions, the first heading shows more means of segmentation than the second one; only in Brandis' edition, however, is the third heading segmented as strongly as the first. Paragraphs, in general, display more uniform procedures.

The selected methods are adopted fairly consistently within one edition, even within the early ones. From this, one can conclude that clear decisions on the layout design were made in advance of the typesetting process and were implemented to a large extent afterwards. It is therefore justified to call these procedures practices of text segmentation. A first tentative approach to evaluating different practices of text segmentation is to measure the overall intensity of segmentation. For this purpose, all headings and paragraphs in the relevant editions were examined with regard to the presence or absence of the outlined means of segmentation. Figure 6 shows the percentage of methods used in each edition (measured against a potential maximum frequency). The percentages in Figure 6 increase 
Table 1: Heading segmentation.

\begin{tabular}{|c|c|c|c|c|c|c|c|c|c|}
\hline & \multicolumn{3}{|c|}{$\begin{array}{l}\text { Leipzig: } \\
\text { Landsberg, 1493/94 }\end{array}$} & \multicolumn{3}{|c|}{$\begin{array}{l}\text { Nuremberg: } \\
\text { Wagner, 1493/94 }\end{array}$} & \multicolumn{3}{|c|}{$\begin{array}{l}\text { Leipzig: } \\
\text { Brandis, 1483/84 }\end{array}$} \\
\hline & 1. & 2. & 3. & 1. & 2. & 3. & 1. & 2. & 3. \\
\hline separate line & $\checkmark$ & $x$ & $x$ & $\checkmark$ & $x$ & $x$ & $\checkmark$ & $x$ & $\bar{S}$ \\
\hline larger type size & $\checkmark$ & $x$ & $x$ & $x$ & $x$ & $x$ & $\checkmark$ & $x$ & $\sqrt{ }$ \\
\hline white space/line break & $\checkmark$ & $x$ & $x$ & $\checkmark$ & $x$ & $x$ & $\checkmark$ & $\checkmark$ & $\sqrt{ }$ \\
\hline pilcrow & $x$ & $x$ & $\checkmark$ & $x$ & $x$ & $\checkmark$ & $x$ & $x$ & $x$ \\
\hline capital letter (beginning) & $\checkmark$ & $\checkmark$ & $\checkmark$ & $\checkmark$ & $\checkmark$ & $\checkmark$ & $\checkmark$ & $\checkmark$ & $\checkmark$ \\
\hline punctuation mark (end) & $x$ & $x$ & $\checkmark$ & $\checkmark$ & $x$ & $x$ & $x$ & $x$ & $x$ \\
\hline
\end{tabular}

Table 2: Paragraph-external segmentation.

\begin{tabular}{|c|c|c|c|c|c|c|c|c|c|}
\hline & \multicolumn{3}{|c|}{$\begin{array}{l}\text { Leipzig: } \\
\text { Landsberg, 1493/94 } \\
\end{array}$} & \multicolumn{3}{|c|}{$\begin{array}{l}\text { Nuremberg: } \\
\text { Wagner, 1493/94 }\end{array}$} & \multicolumn{3}{|c|}{$\begin{array}{l}\text { Leipzig: } \\
\text { Brandis, 1483/84 }\end{array}$} \\
\hline & 1. & 2. & 3. & 1. & 2. & 3. & 1. & 2. & 3. \\
\hline separate text block & $x$ & $x$ & $x$ & $x$ & $x$ & $x$ & $x$ & $x$ & $\checkmark$ \\
\hline white space/line break & $x$ & $x$ & $x$ & $x$ & $x$ & $x$ & $x$ & $x$ & $x$ \\
\hline pilcrow & $\checkmark$ & $x$ & $x$ & $\checkmark$ & $x$ & $x$ & $x$ & $x$ & $x$ \\
\hline capital letter (beginning) & $\checkmark$ & $x$ & $\checkmark$ & $\checkmark$ & $x$ & $\checkmark$ & $\checkmark$ & $\checkmark$ & $\checkmark$ \\
\hline punctuation mark (end) & $\checkmark$ & $\checkmark$ & $x$ & $\checkmark$ & $\checkmark$ & $\checkmark$ & $\checkmark$ & $\checkmark$ & $\checkmark$ \\
\hline
\end{tabular}

from the inside to the outside of the circle. The data are listed in more detail in the Appendix.

What is most noticeable is that in the earlier editions up to 1490 (no. 11) there was quite a lot of experimentation with segmentation intensity. The texts are segmented either weakly or quite strongly (between $27 \%$ and $56 \%$ ). From text no. 12 onward, the intensity of segmentation stabilizes at a medium level of about $40 \%$. In practice, certain preferences seem to have existed for the combination of various methods. For instance, headings in a separate line would usually appear with white space before and after it, and normally start with a capital letter. ${ }^{33}$ Most irregular is the use of punctuation marks. In general, it can be said that punctuation marks are used more frequently at the end of paragraphs than headings. Yet in some editions (e. g. in no. 3 and 17) about every second heading ends with a

33 Some printers apparently did not possess a type for capital $W$ (cf. e. g. GW 9577, GW 9582, GW 9584). The months of October (Weinmond), November (Wintermond) and December (Wolfsmond) therefore appear with a lower case $w$. Cf. Dane (2012: 118). 


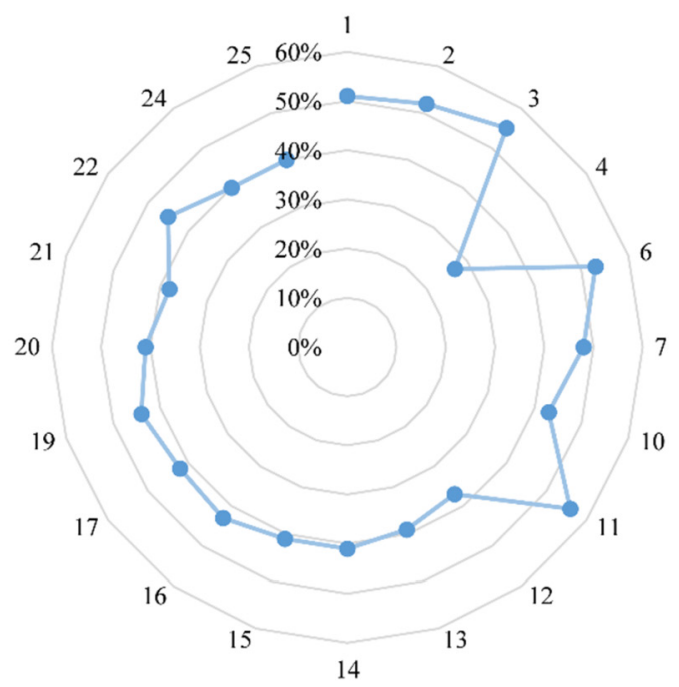

Figure 6: Intensity of segmentation.

\author{
Leipzig: Brandis, 1481/82 \\ Leipzig: Brandis, 1483/84 \\ Nuremberg: Creussner, 1484/85 \\ Nuremberg: Wagner, 1485/86 \\ Augsburg: Sorg, 1486/87 \\ Nuremberg: Creussner, 1486/87 \\ Nuremberg: Wagner, 1489/90 \\ Mainz: Schöffer, 1489/90 \\ Leipzig: Boettiger, 1491/92 \\ Leipzig: Landsberg, 1491/92 \\ Lübeck: Ghotan, 1491/92 \\ Leipzig: Landsberg, 1492/93 \\ Leipzig: Landsberg, 1493/94 \\ Nuremberg: Wagner, 1493/94 \\ Nuremberg: Koberger, 1494/95 \\ Nuremberg: Wagner, 1495/96 \\ Leipzig: Landsberg, 1496/97 \\ Magdeburg: Brandis, 1496/97 \\ Leipzig: Landsberg, 1497/98 \\ Nuremberg: Wagner, 1497/98
}

point, whereas paragraphs in other editions (e.g. in no. 1, 4 and 21) are hardly ever terminated by a punctuation mark.

Although the intensity of segmentation converged, segmentation practices were still not entirely uniform in the 1490s. In Leipzig, however, a local style had emerged (as illustrated in Figure 4, left), which can be found not only in Boettiger's and Landsberg's editions (no. 12, 13, 15, 16, 21, and 24), but also in the Koberger edition from Nuremberg (no. 19) and (in a slightly modified form) in Brandis' edition from Magdeburg (no. 22). Since the "Leipzig style" was applied more and more stringently and adopted by other (though not all) printers, it is arguably fair to designate this practice as the generic layout or "signature style" of Faber's later practicas. Naturally, it is difficult to assess whether the "Leipzig style" prevailed because it was particularly suitable and effective in terms of reader orientation or because Leipzig was Faber's domain and preferred printing location. Still, it is an important finding that the text segmentation of certain text types gained stability towards the end of the incunable period.

\subsection{Paragraph-internal capital letters and punctuation marks}

Capital letters and punctuation marks which stand within a paragraph (excluding the beginning or end of a paragraph) can fulfil different functions. As discussed 
in Section 4.1, capital letters can be used to indicate the beginning of a semantically and syntactically self-contained unit, cf. (4), and to denote specific nouns, namely nomina propria and nomina sacra, cf. (5). ${ }^{34}$ Both functions can overlap, as illustrated in (6). ${ }^{35}$

(4) Am abēt der heyligē drey konig Jtarcke vnd merckliche bewegung der wind mit Jchne Am tag der heyligen drey ko̊nig Jchne (Leipzig: Landsberg, 1491/92) 'In the evening of epiphany strong and noticeable movement of the wind with snow On the day of epiphany snow'

(5) Bey dem Sōtag vor Clementis gewulckñ mit regē (Nuremberg: Wagner, 1489/90)

'On Sunday before Clement clouds with rain'

(6) Sunntag nach viti auff die nacht windt · vnd in vil ennden mit mesfigē doner Erichtag vor Johannis tauffer wandlung · (Augsburg: Sorg, 1486/87)

'Sunday after vitus at night wind · and in many points with moderate thunder Tuesday before John baptist change .'

Likewise, there are two main functions for punctuation marks. The first one is to structure a paragraph according to semantic and syntactic aspects. Due to the stereotypical linguistic patterns in the moon phase chapter, three specific cases can be distinguished here: similar to capital letters, punctuation marks can separate two semantically and syntactically self-contained units, cf. (7-a). They can also occur between a specific day and the respective weather description, cf. (7-b). And they are occasionally used in contexts of coordination, cf. (7-c). The second main function is the identification of numbers in conjunction with an abbreviation of units of measurement as in (8).

(7) a. Sontag nach der heiligen dry konig tag feuchtnuß 3 yn etlichen enden den tag darnach • (Mainz: Schöffer, 1489/90)

'Sunday after epiphany humidity • in many points the day after .'

b. Bei dem dinftage nach vnfer frawen . kalde wint mit trubūg der lufft vnd regē (Leipzig: Brandis, 1483/84)

'On tuesday after mary . cold wind with misty air and rain'

34 On different subgroups of nomina propria and nomina sacra, see Bergmann and Nerius (1998: 49-57).

35 In the analysis, capital letters with both functions were counted separately (cf. the table in the Appendix). In Figures 7 and 8, they are included in the numbers for the structuring of paragraphs. 
c. Am Juntag vor conuerfionis pauli wolken . vnd wind. $v \bar{n}$ dar bei feuchtikeit. (Nuremberg: Creussner, 1484/85)

'On sunday before conversion of paul clouds . and wind . and accompanying humidity.'

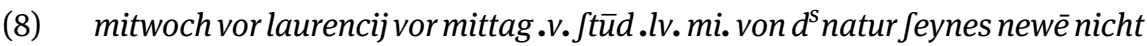
tretē wyrt. (Leipzig: Landsberg, 1491/92)

'wednesday before lawrence midmorning .v. hours .lv. mi. will not deviate from the nature of its new [moon].'

The marking of nomina propria/nomina sacra and the identification of numbers/abbreviations are functions specifically associated with capital letters and punctuation marks. The function of text segmentation, however, can be fulfilled by both methods. Of great interest is the question of whether typesetters used capital letters and punctuation marks monofunctionally (i. e., either for text segmentation or for nomina propria/nomina sacra and numbers/abbreviations) or polyfunctionally (i. e., both for text segmentation and for nomina propria/nomina sacra or numbers/abbreviations). Figure 7 shows the percentage of capital letters (in blue) and punctuation marks (in red) that denote nomina propria/nomina sacra or numbers/abbreviations. The lower the rate, the less capital letters and punctuation marks were used in the respective functions. Instead, we can assume that capital letters and punctuation marks were increasingly used for purposes of text segmentation. In the medium range (from $33 \%$ to $66 \%$ ) a polyfunctional usage can be claimed.

In the majority of editions, capital letters were used monofunctionally for purposes of text segmentation. Only in some editions can a polyfunctional approach be detected. But there are no cases in which capital letters were used mainly for nomina propria and nomina sacra. ${ }^{36}$ With punctuation marks, matters are quite to the contrary. Punctuation marks were rarely used for text segmentation only. In most editions, they were used polyfunctionally or monofunctionally for numbers and abbreviations. Overall, there is a strong tendency towards monofunctional usages: while in the 1480s capital letters and punctuations marks were used in all possible functions, a clear distribution became established in the 1490s, with capital letters used primarily for paragraph-internal segmentation and punctuation marks for numbers and abbreviations. In order to find an explanation for this development, the interaction of capital letters and punctuation marks must be examined more closely.

36 Since semantic-syntactic units usually contain at least one nomen proprium/nomen sacrum (cf. Figure 5), the overall ratio between the two is relatively balanced. 


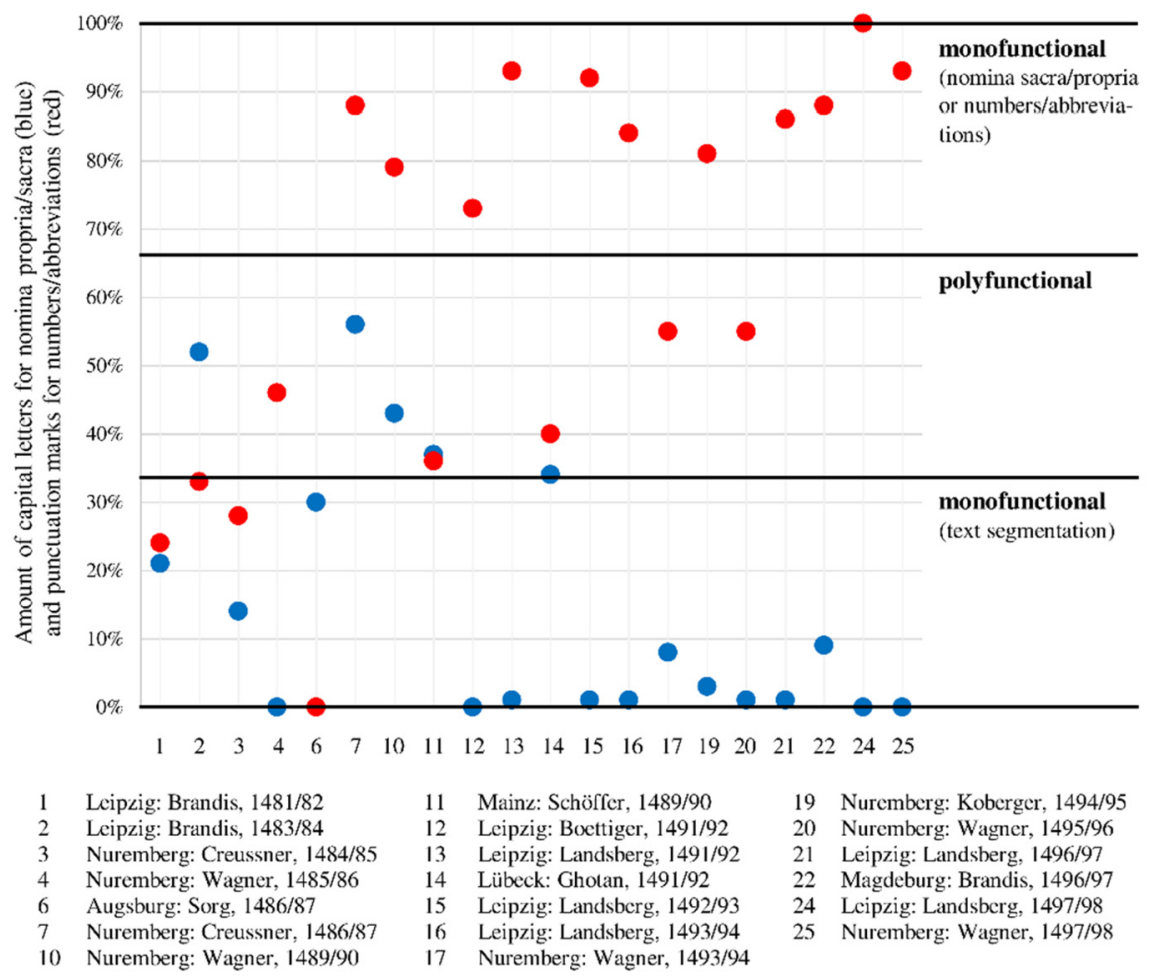

Figure 7: Monofunctional and polyfunctional uses of capital letters (blue) and punctuation marks (red).

In the following I will only consider capital letters and punctuation marks that are used for paragraph-internal structuring. To define types of text segmentation, it seems appropriate to take two variables into account: first, the frequency, indicated by the ratio of capital letters to punctuation marks; second, the cooccurrence of capital letters and punctuation marks, indicated by the percentage of corresponding usage (cf. Figure 8). These two variables depend on each other in that $100 \%$ co-occurrence (i. e. capital letters and punctuation marks always appear together) requires that the amount of capital letters and punctuation marks are exactly the same (i. e. in a ratio of 1:1). Conversely, however, a co-occurrence of $0 \%$ does not necessarily mean that capital letters and punctuation marks occur at different frequencies. They may also occur equally often but in diverging positions and thus fulfil different tasks in the segmentation process. The division of the grid into even sections verified by at least one edition from the corpus leads 


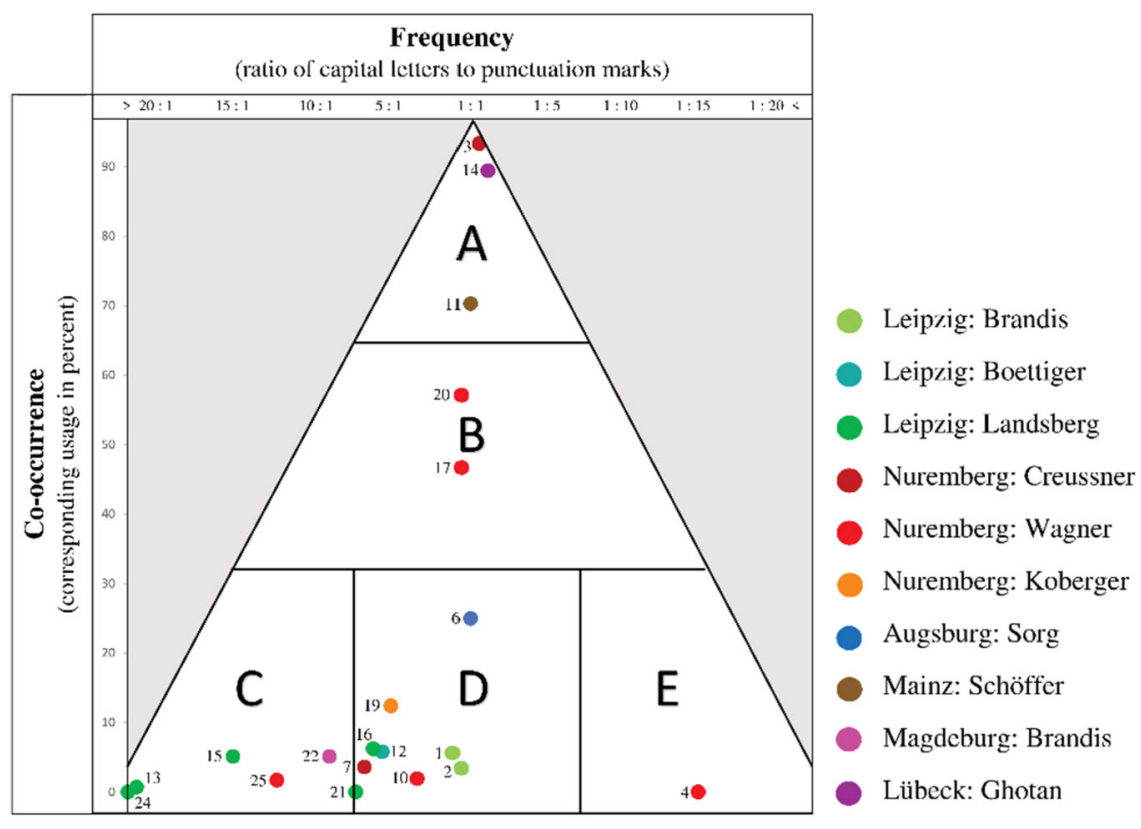

Figure 8: Types of paragraph-internal segmentation.

to the distinction of five types of paragraph-internal segmentation, illustrated by instructive samples in Figure 9.

The most common types are $\mathrm{C}$ and $\mathrm{D}$ : about half of the editions investigated form a cluster in the intermediate area of these two types. Both types are characterized by the fact that capital letters and punctuation marks rarely appear together in the same linguistic positions. Whereas in $C$ this is primarily due to the dominance of capital letters, which only serve to mark the beginning of a semanticsyntactic unit, type D applies a differentiated principle in various respects. Both capital letters and punctuation marks are equally frequent. They fulfil different tasks in the segmentation process and have therefore become specialized means of paragraph-internal segmentation. In some editions, the inventory of punctuation marks is even larger than in others, deploying the point and the virgule for different purposes of segmentation.

In type A, capital letters and punctuation marks are about the same in frequency and occur mainly side by side, marking the same linguistic positions, namely the boundary between two semantic-syntactic units. This type, which, in the long run, has become established for the demarcation of sentence boundaries, can be described as a system of mutual reinforcement. Type B is 
Cöscptöigmaric vit in Setne togte

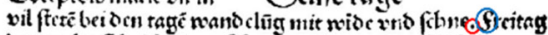

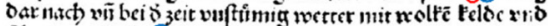

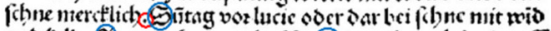

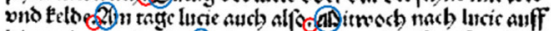

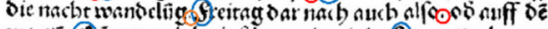

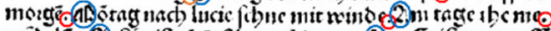

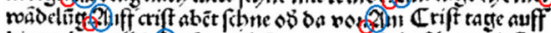

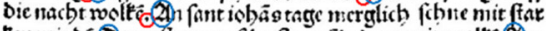

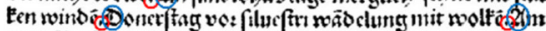
tage filue tri auff oic nacht glcieb alfo.

Type $\Lambda$ (Nuremberg: Creussner, 1484/85)

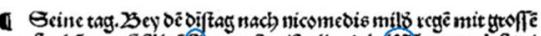

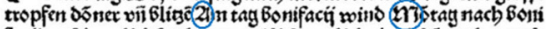

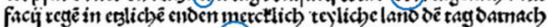

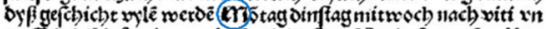
mefifkecit $\$$ luft tuit gevoulcté woino vil regé Bey oyfen tagé vyllan

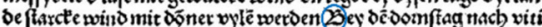
milo regé vinvilleycht an vil endẽ den fonabét darnach mit merct"

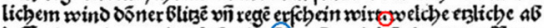
laffen Der woirm nachuolge evirt chict't t3 feuchtn' etliche ende am taa bie i) nach iobäniegobteuffer woino (r) Type B (Nuremberg: Wagner, 1493/94)

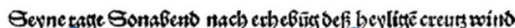

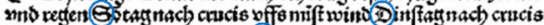
feucherus miterlicherteloen (25ey oes fonabeno nach mathei fut

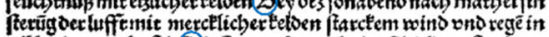

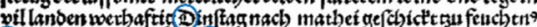

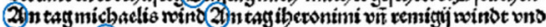

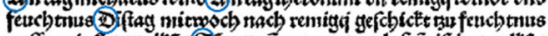
auffis mim

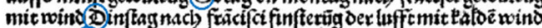

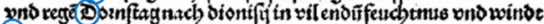
(25) a

Type C (Leipzig: Landsberg, 1497/98)
Entige tag an:ffons:

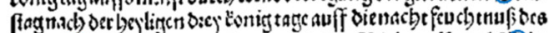

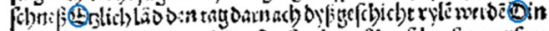

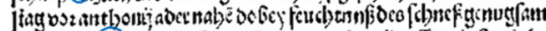

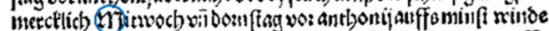

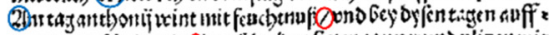

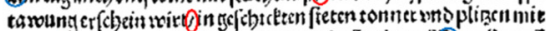

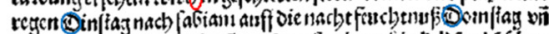

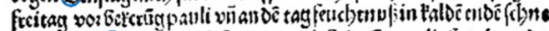

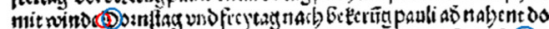

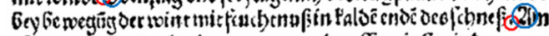

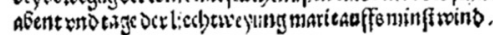

Type D (Leipzig: Landsberg, 1493/94)

Sem

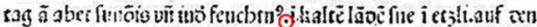

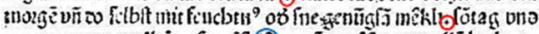

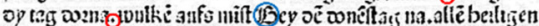

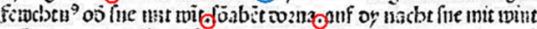

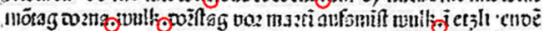

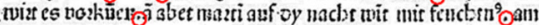

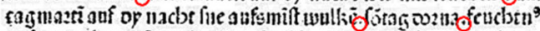

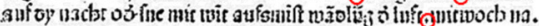

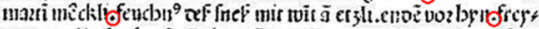

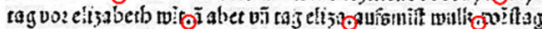

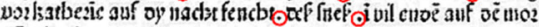
gẽ nit wît

Type E (Nuremberg: Wagner, 1485/86)

Figure 9: Text samples for types of paragraph-internal segmentation.

a mixed system covering the entire range of possible functions: capital letters and punctuation marks are used together, but also separately for different structuring purposes. When marking sentence boundaries, typesetters differentiate between a weak form of demarcation (use of punctuation marks or capital letters) and a strong form of demarcation (use of punctuation marks and capital letters).

Type $\mathrm{E}$ is a rather unusual case to which only one edition can be assigned. It predominantly uses punctuation marks for various structuring (sub)functions. The text sample in Figure 9 shows that little orientation for the reader is provided when the same characters are used extensively for many different purposes (not even taking into account punctuation marks for indication of numbers and abbreviations). This might also offer a replicable explanation for why monofunctional uses of capital letters and punctuation marks gained ground during the period investigated here. Without coherent, established layout conventions, polyfunctional uses complicate the reading process instead of helping the reader to decode information. 
Although no chronological trends can be identified, Figure 8 reveals some interesting printer specifics. While Markus Brandis took a very similar approach in both of his editions, his Leipzig colleague Martin Landsberg varied quite a bit with regard to the ratio of capital letters and punctuation marks. Even more so, the Nuremberg editions by Peter Wagner and Friedrich Creussner differ in almost every respect. Thus one can assume that these typesetters did not reproduce the layout of former editions, but instead tested different possibilities in their search for suitable forms of text segmention.

\section{Conclusion}

This case study has shown that segmentation in the early phase of letterpress printing was by no means arbitrary and idiosyncratic; however, the assumption of a syntactic principle, which implies that texts were intentionally structured according to (purely) syntactic aspects using similar methods, does not comprehensively reflect the actual procedures in late medieval print shops either. Kirchhoff's (2017: 169-171) analysis of two 15th-century texts indicates a predominantly syntactically based, albeit inconsistent, use of punctuation marks, with capital letters used primarily to mark the beginning of sentences. However, this usage demonstrates only one of several competing punctuation practices at this time. Using 26 editions of German practices by Wenzel Faber, I have attempted to demonstrate the necessity to take into account that a uniform modus operandi among typesetters had not yet become established, and to consider punctuation in a larger context of text segmentation tasks.

Even if the incunable period in general was an experimental phase, substantial differences between the editions before and after 1490 can be observed. These differences are to be seen as independent from changes in the content structure, as incisive changes did not overlap in time. At first, the layout as a whole was involved: it initially showed strong variation in segmentation intensity, but became more and more uniform after 1490. Moreover, the interplay between paragraphinternal capital letters and punctuation marks shifted in favor of a growing preference for monofunctional uses. In this, capital letters were primarily used for text segmentation, and punctuation marks for indication of numbers and abbreviations. Polyfunctional uses, however, were soon abandoned, because without fixed layout conventions, such uses tended to obscure rather than reveal the structure of a text. For the relationship between text segmenting capital letters and punctuation marks, I have distinguished five types of segmentation, each characterized by a specific ratio of frequency and co-occurrence of methods. These types are not 
subject to a chronological development, yet printer-specific uses among Leipzig and Nuremberg printers have become apparent. This underlines the assumption that craftsmen in the print shops did not work arbitrarily at all. When examining comparable text samples, one can find many internal regularities and even the beginnings of systematic approaches.

In the future, research must focus more closely on these fundamentals of writing systems. Of particular importance are the effects of typesetting on the linguistic form of printed texts. After all, capital letters and punctuation marks could only develop their full linguistic potential once text segmentation had become settled. 


\section{Appendix. Analyzed data}

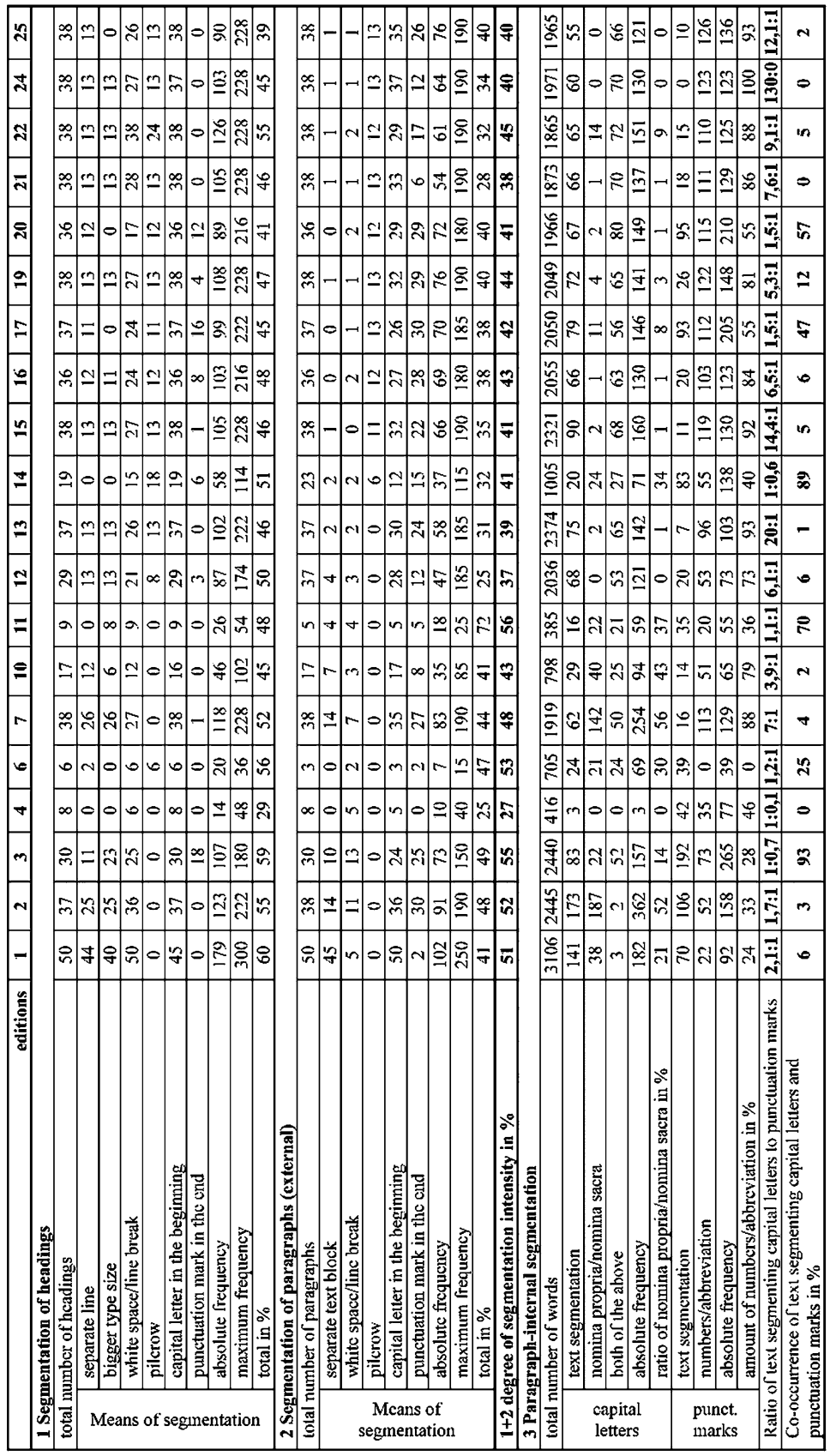




\section{Corpus}

\begin{tabular}{lllll}
\hline Nr. & Year & Place & Printer & Identification \\
\hline 1 & $1481 / 82$ & Leipzig & Markus Brandis & GW 9577 \\
2 & $1483 / 84$ & Leipzig & Markus Brandis & GW 9582 \\
3 & $1484 / 85$ & Nuremberg & Friedrich Creussner & GW 9584 \\
4 & $1485 / 86$ & Nuremberg & Peter Wagner & GW 9587 \\
5 & $1486 / 87$ & Passau & Johann Petri & GW 9591 \\
6 & $1486 / 87$ & Augsburg & Anton Sorg & GW 959010 \\
7 & $1486 / 87$ & Nuremberg & Friedrich Creussner & GW 959020N \\
8 & $1488 / 89$ & Leipzig & Priamus Capotius & GW 959310N \\
9 & $1489 / 90$ & Nuremberg & Friedrich Creussner & GW 9596 \\
10 & $1489 / 90$ & Nuremberg & Peter Wagner & GW 959620N \\
11 & $1489 / 90$ & Mainz & Peter Schöffer & GW 9586 \\
12 & $1491 / 92$ & Leipzig & Gregor Boettiger & GW 9601 \\
13 & $1491 / 92$ & Leipzig & Martin Landsberg & GW 9602 \\
14 & $1491 / 92$ & Lübeck & Bartholomäus Ghotan & University of Warsaw Library \\
& & & & Sd.52.79 adl. \\
15 & $1492 / 93$ & Leipzig & Martin Landsberg & GW 9606 \\
16 & $1493 / 94$ & Leipzig & Martin Landsberg & GW 9608 \\
17 & $1493 / 94$ & Nuremberg & Peter Wagner & GW 9609 \\
18 & $1494 / 95$ & Nuremberg & Friedrich Creussner & GW 9611 \\
19 & $1494 / 95$ & Nuremberg & Anton Koberger & GW 9612 \\
20 & $1495 / 96$ & Nuremberg & Peter Wagner & GW 9617 \\
21 & $1496 / 97$ & Leipzig & Martin Landsberg & GW 9619 \\
22 & $1496 / 97$ & Magdeburg & Moritz Brandis & GW 9620 \\
23 & $1497 / 98$ & Erfurt & Heidericus and Marx Ayrer & GW 9622 \\
24 & $1497 / 98$ & Leipzig & Martin Landsberg & GW 9623 \\
25 & $1497 / 98$ & Nuremberg & Peter Wagner & GW 9624 \\
26 & $1498 / 99$ & Leipzig & Konrad Kachelofen (?) & GW 962510 \\
\hline & & & &
\end{tabular}

\section{References}

Almeida, Francisco A. 2001. Punctuation practice in a late medieval English medical remedybook. Folia Linguistica Historica XXII(1-2). 207-232.

von Ammon, Frieder \& Herfried Vögel (eds.). 2008. Die Pluralisierung des Paratextes in der Frühen Neuzeit. Theorie, Formen, Funktionen. Münster: LIT-Verlag.

Bergmann, Rolf \& Dieter Nerius. 1998. Die Entwicklung der Großschreibung im Deutschen von 1500 bis 1700. 2 Vol. (Germanische Bibliothek 29). Heidelberg: Winter.

Dane, Joseph A. 2012. What is a book? The study of early printed books. Notre Dame, IN: University of Notre Dame Press.

Franck, Jakob. 1883. Landsberg, Martin. Allgemeine Deutsche Biographie 17. 595-596.

Geldner, Ferdinand. 1968. Die deutschen Inkunabeldrucker. Ein Handbuch der deutschen Buchdrucker des XV. Jahrhunderts nach Druckorten. Vol. 1: Das deutsche Sprachgebiet. 
Stuttgart: Hiersemann.

Genette, Gérard. 1997. Paratexts. Thresholds of interpretation (Literature, Culture, Theory 20). Cambridge: Cambridge University Press.

Grafton, Anthony. 2011. The culture of correction in Renaissance Europe. London: British Library.

Green, Jonathan. 2011. Printing and prophecy. Prognostication and media change 1450-1550 (Cultures of Knowledge in the Early Modern World). Ann Arbor, MI: University of Michigan Press.

Green, Jonathan. 2012. Printing the future. The origin and development of the Practica Teütsch to 1620. Archiv für Geschichte des Buchwesens 67.1-18.

Green, Jonathan \& Oliver Duntze. 2013. Johannes von Glogau and the earliest German practicas. Gutenberg-Jahrbuch 88. 68-85.

Griese, Sabine. 2017. Layoutformen des Buchs im 15. Jahrhundert. In Christoph Reske \& Wolfgang Schmitz (eds.), Materielle Aspekte in der Inkunabelforschung (Wolfenbütteler Schriften zur Geschichte des Buchwesens 49), 9-42. Wiesbaden: Harrassowitz.

Habermann, Mechthild. 2001. Deutsche Fachtexte der frühen Neuzeit. Naturkundlichmedizinische Wissensvermittlung im Spannungsfeld von Latein und Volkssprache (Studia Linguistica Germanica 61). Berlin \& New York: de Gruyter.

Haebler, Konrad. 1914. Paulus Eck gegen Wenzel Faber. Zeitschrift für Bücherfreunde 6. 200-204.

Janssen, Frans A. 2005. The rise of the typographical paragraph. In Karl A. E. Enenkel \& Wolfgang Neuber (eds.), Cognition and the book. Typologies of formal organizations of knowledge in the printed book of the early modern period (Intersections 4), 9-34. Leiden: Brill.

Kirchhoff, Frank. 2017. Von der Virgel zum Komma. Die Entwicklung der Interpunktion im Deutschen. Heidelberg: Winter.

Kremer, Richard. 2017. Incunable almanacs and practica as practical knowledge produced in trading zones. In Matteo Valleriani (ed.), The structures of practical knowledge, 333-369. Dordrecht: Springer.

Laufer, Roger. 1983. L'espace visuel du livre ancien. In Henri-Jean Martin \& Roger Chartier (eds.), Histoire de l'édition française, Vol. 1: Le livre conquérant: du Moyen Âge au milieu du XVIle siècle, 479-497. Paris: Promodis.

Lemke, Ilka. 2020. Das Komma. Zur syntaktisch-graphematischen Klassifikation des Zeichens im Sprach- und Schriftsystem des Deutschen und zur historischen Entwicklung aus formaler und funktionaler Perspektive (Deutsche Sprachgeschichte 10). Bern: Peter Lang.

Lennard, John. 1995. Punctuation: And - 'pragmatics'. In Andreas H. Jucker (ed.), Historical pragmatics. Pragmatic developments in the history of English, 65-98. Amsterdam: John Benjamins.

Masalon, Kevin C. 2014. Die deutsche Zeichensetzung gestern, heute - und morgen (?). Eine korpusbasierte, diachrone Untersuchung der Interpunktion als Teil schriftsprachlichen Wandels im Spannungsfeld von Textpragmatik, System und Norm unter besonderer Berücksichtigung des Kommas. Duisburg: Universität Duisburg-Essen dissertation. https://duepublico.uni-duisburg-essen.de/servlets/DerivateServlet/Derivate-36075/ Dissertation_Masalon.pdf (accessed 30 September 2020).

Milway, Michael. 2000. Forgotten best-sellers from the dawn of the Reformation. In Robert J. Bast \& Andrew C. Gow (eds.), Continuity and change. The harvest of Late Medieval and Reformation history, 113-142. Leiden: Brill. 
Neumann, Marko \& Anja Voeste. 2022. Textsegmentierung in Handschrift und Frühdruck. In Paul Rössler, Peter Besl \& Anna Saller (eds.), Comparative punctuation - Vergleichende Interpunktion. Berlin \& Boston: De Gruyter.

Parkes, Malcolm. 1992. Pause and effect. An Introduction to the history of punctuation in the West. Aldershot: Scolar Press.

Rautenberg, Ursula. 2018. Das Buch in der Codexform und einblättrige Lesemedien. In Ursula Rautenberg \& Ute Schneider (eds.), Lesen. Ein interdisziplinäres Handbuch, 279-336. Berlin \& Boston: De Gruyter.

Reske, Christoph. 2015. Die Buchdrucker des 16. und 17. Jahrhunderts im deutschen Sprachgebiet. Auf der Grundlage des gleichnamigen Werkes von Josef Benzing. 2nd edn. Wiesbaden: Harrassowitz.

Schmitz, Wolfgang. 2018. Grundriss der Inkunabelkunde. Das gedruckte Buch im Zeitalter des Medienwechsels (Bibliothek des Buchwesens 27). Stuttgart: Hiersemann.

Simmler, Franz. 2003. Geschichte der Interpunktionssysteme im Deutschen. In Werner Besch, Anne Betten, Oskar Reichmann \& Stefan Sonderegger (eds.), Sprachgeschichte. Ein Handbuch zur Geschichte der deutschen Sprache und ihrer Erforschung (Handbücher zur Sprach- und Kommunikationswissenschaft 2.3), 2472-2504. 2nd edn. Berlin \& New York: De Gruyter.

Smith, Jeremy J. 2019. Textual form and textual function: Punctuation and the reception of early English texts. In Claudia Claridge \& Merja Kytö (eds.), Punctuation in context - past and present perspectives (Linguistic Insights 263), 131-150. Bern: Peter Lang.

Spitzmüller, Jürgen. 2013. Graphische Variation als soziale Praxis. Eine soziolinguistische Theorie skriptualer „Sichtbarkeit“ (Linguistik - Impulse \& Tendenzen 56). Berlin \& Boston: De Gruyter.

Stein, Stephan. 2003. Textgliederung. Einheitenbildung im geschriebenen und gesprochenen Deutsch: Theorie und Empirie (Studia Linguistica Germanica 69). Berlin \& New York: De Gruyter.

Voeste, Anja. 2018. Interpunktion und Textsegmentierung im frühen deutschsprachigen Prosaroman. Beiträge zur Geschichte der deutschen Sprache und Literatur (PBB) 140. $1-22$.

Voeste, Anja. 2020. Zukunft von gestern. Wenzel Fabers Prognostiken als sprachhistorische Quelle. In Jana Kusová (ed.), Germanistik zwischen Mittelalter und Gegenwart, 145-159. Wien: Praesens. 